\title{
MANAJEMEN KEPALA SEKOLAH DALAM MENUMBUHKAN BUDAYA RELIGIUS PESERTA DIDIK DI SDN BANJARWATI KECAMATAN PACIRAN KABUPATEN LAMONGAN
}

\author{
Hikmatul Fitriya ${ }^{1)}$, Muh. Hasyim Rosyidi ${ }^{2)}$ \\ Institut Pesantren Sunan Drajat Lamongan \\ Email: hikmatul.fitriyah97@gmail.com¹, hasyimrisyidi@gmail.com²
}

Dikirim:15 April 2020 | Direvisi: 20 Juli 2020 | Dipublikasikan: 31 Juli 2020

\begin{abstract}
Abstraksi: Manajemen kepala sekolah dalam menumbuhkan budaya religius peserta didik di SDN Banjarwati dikarenakan banyak sekolah saat ini dipenuhi oleh generasi milenial, begitupun di SDN Banjarwati. Generasi milenial saat ini sangat minin pengetahuan agama islam, untuk itu pihak sekolah berusaha tidak hanya mengajarkan materi agama islam tetapi juga praktek kegiatan religius sebagai bentuk implementasi dari materi tersebut. Kegiatan-kegiatan religius pasti ada struktur manajerialnya, untuk itu kepala sekolah hendaknya memiliki kompetensi manajerial yang baik. Guna mengetahui permasalahan dan mendapatkan data yang akurat, peneliti menggunakan metode observasi, wawancara serta dokumentasi. Dan menggunakan teknik analisis deskriptif kualitatif. Dari penelitian ini dapat dikatakan bahwa Manajemen kepala sekolah dalam menumbuhkan budaya religius peserta didik di SDN Banjarwati adalah suatu bentuk usaha yang dilakukan oleh kepala sekolah dengan cara mengadakan berbagai program yang dapat membentuk karakter religius peserta didik sehingga nantinya dapat menjadi suatu kebiasaan berperilaku dan bertindak yang baik bagi peserta didik serta dapat menjadikan peserta didik yang berakhlakul karimah. Sementara itu, Upaya-upaya yang dilakukan kepala sekolah untuk menumbuhkan budaya religius peserta didik yakni dengan cara mengadakan dan menerapkan kegiatan-kegiatan yang bersifat islami. Adapun kegiatan-kegiatan religius yang diadakan SDN Banjarwati yakni: a) Apel Pagi atau Do'a Bersama Sebelum Memasuki Ruang Kelas, b) Sholat Dhuha, c) Sholat Dhuhur Berjama’ah, d) Membaca Al-Qur'an, Juz Amma dan Asma’ul Khusnah. Adapun faktor pendukung kepala sekolah dalam menumbuhkan budaya religius peserta didik yakni: a) Guru yang kompeten dalam bidangnya dan sangat memperhatikan kondisi pendidikan, b) Tersedianya fasilitas musholah, c) Semangat kepala sekolah dan dewan guru, d) Antusiasme peserta didik dalam mengikuti kegiatan religius, e) Ketersediaan buku/kitab pegangan siswa. Sedangkan faktor penghambat kepala sekolah dalam menumbuhkan budaya religius peserta didik yakni: a) Dana sebagai faktor pengahambat paling utama, b) Jumlah guru yang terbatas, c) Guru yang lebih mementingkan kepentingan pribadinya, d) Peserta didik yang membandel tidak mengikuti kegiatan-kegiatan religius.

Kata kunci: Budaya religius; kepala sekolab; manajemen.
\end{abstract}

\section{Pendahuluan}

Pendidikn sebagai usaha sadar dan terencana untuk untuk mewujudkan suasana belajar dan proses pembelajaran agar peserta didik secara aktif mengembangkan potensi dirinya untuk memiliki kekuatan spiritual keagamaan, pengendalian diri, kepribadian, kecerdasan, akhlak mulia, serta keterampilan yang diperlukan dirinya, masyarakat, bangsa dan negara. ${ }^{1}$ Keberhasilan suatu lembaga

\footnotetext{
${ }^{1}$ Undang-undang Republik Indonesia Nomor 20 Tahun 2003 tentang Sistem Pendidikan Nasional, Bab 1 Ketentuan Umum pasal 1 ayat 1
} 
pendidikan merupakan keberhasilan kepala sekolah, karena keberhasilan suatu lembaga pendidikan sangat bergantung kepada peran seorang kepala sekolah. Bagaimanapun, seorang kepala sekolah merupakan pemimpin sebuah lembaga pendidikan formal yang bertanggung jawab terhadap kelangsungan belajar mengajar, serta mengembangkan potensi yang ada dilembaga tersebut. ${ }^{2}$

Seorang kepala sekolah yang baik, kreatif dan inovatif, beliau akan mempersiapkan dan mengadakan berbagai program tambahan untuk lembaganya. Setiap lembaga pendidikan diharapkan mempuyai suatu kelebihan yang positif, seperti berupa budaya religius yang diberdayakan oleh lembaga sebagai suatu usaha kepala sekolah dalam membentuk peserta didik yang berakhlakul karimah.

Banyak sekali sekolah saat ini dipenuhi oleh generasi milenial. Generasi ini lahir di era tahun 1990 ke atas. Mereka kerap dituding sebagai generasi yang manja, motivasi belajar yang kurang, susah diatur, kurang memiliki rasa hormat dan sangat aktif sekali di media sosial. Untuk itu, generasi milenial ini sangat memerlukan pengawasan yang ketat agar mereka dapat menjadi generasi yang hebat. Selain memerlukan pengawasan, mereka juga memerlukan feedback, perhatian dan penghargaan. Generasi milenial, siswa milenial, anak-anak milenial membutuhkan seorang figur yang care kepada mereka, gemar berdiskusi, memberi bimbingan dalam komunikasi yang seimbang, dan memberi nasehat yang tidak menggurui.

Seorang kepala sekolah hendaknya memiliki kompetensi manajerial yang baik. Karena kepala sekolah memiliki salah satu peran yaitu sebagai manajer. Manajer pada hakikatnya adalah seorang perencana, organisator, pemimpin dan seorang pengendali, keberadaan manajer pada suatu organisasi sangat diperlukan, sebab organisasi sebagai alat untuk mencapai tujuan organisasi dimana didalamnya berkembang berbagai pengetahuan, serta organisasi yang menjadi tempat untuk membina dan mengembangkan karir-karir sumber daya manusia, memerlukan manajer yang mampu merencanakan, mengorganisasikan, memimpin dan mengendalikan agar organisasi dapat mencapai tujuan yang telah ditetapkan. ${ }^{3}$

SDN Banjarwati adalah Sekolah Dasar Negeri yang terletak di desa Banjarwati, Paciran, Lamongan, Jawa Timur, Indonesia. SDN Banjarwati terletak di desa Banjarwati yang berdekatan dengan desa Drajat yang terdapat Makam Kanjeng Sunan Drajat. Sekolah yang memiliki Visi

\footnotetext{
${ }^{2}$ Wahjosumidjo, Kepemimpinan Kepala Sekolah (Jakarta: Rajawali Pers, 2008), 81

${ }^{3}$ Ibid., 96-97.
} 
“UNGGUL DALAM PRESTASI DAN BERAKHLAKUL KARIMAH” ini memiliki banyak prestasi ditingkat kecamatan maupun kabupaten. Sebagai salah satu sekolah umum yang mana masyarakat sekitarnya lebih banyak memilik Madrasah yang sudah pasti akan program keagamaannya, namun dengan ditunjang dengan sarana dan prasarana yang cukup memadai, SDN Banjarwati memiliki keinginan untuk menumbuhkan dan menanamkan nilai-nilai ajaran agama islam dengan menerapkan program/kegiatan religius sehingga pada proses perkembangan peserta didik kedepannya menjadi peseta didik yang berakhlakul karimah. SDN Banjarwati juga memiliki keinginan yang kuat untuk mencetak lulusan-lulusan yang tidak hanya unggul dalam prestasi, akan tetapi juga unggul dalam aspek spiritual. Hal ini tercermin didalam visi sekolah tersebut.

Dalam proses manajemen disana mulai dari Proses Perencanaan, perencanaan kegiatankegiatan religius di SDN Banjarwati sudah tersusun dengan baik, dibuktikan denga adanya dokumen struktural kegiatan yang jelas. Proses Pengorganisasian, pengorganisasian dalam kegiatankegiatan religius di SDN Banjarwati sudah tertata dengan baik, dibuktikan dengan adanya kepastian pihak yang bertanggung jawab akan pelaksanaan kegiatan-kegiatan religius tersebut. Proses Pergerakan, implementasi atau pelaksanaan dari semua kegiatan-kegiatan religius di SDN Banjarwati terlaksana dengan baik, para peserta didik juga banyak yang aktif dalam berpartisipasi. Proses Pengawasan, dalam kegiatan-kegiatan religius di SDN Banjarwati sudah ada pengawasan dan pemantauan yang pasti dari pelaksanaan kegiatan-kegiatan religius tersebut, sehingga dapat diketahui dengan jelas apakah kegiatan-kegiatan religius tersebut berhasil diterapkan atau tidak, dan juga tidak ada penanggulangan/bentuk tindak lanjut jika kegiatan-kegiatan religius tersebut tidak berjalan sesuai yang di harapkan. Tidak hanya proses manajemen, peneliti juga menemukan berbagai faktor-faktor yang menjadi penghambat dan pendukung dalam menumbuhkan budaya religius peserta didik disana, diantaranya dari sarana prasarana sekolah, tenaga pendidik dan kependidikan dan juga dari peserta didik itu sendiri. ${ }^{4}$

\section{Metode Penelitian}

\section{Pendekatan dan Jenis Penelitian}

Pada penelitian ini, peneliti menggunakan pendekatan penelitian kualitatif. Menurut Moleong, "Penelitian kualitatif adalah suatu penelitian yang bermaksud untuk memahami fenomena tentang sesuatu yang dialami oleh subjek penelitian misalnya perilaku, persepsi, motivasi, tindakan dan lainlain secara holistik, dan dengan cara mendeskripsikan ke dalam bentuk kata-kata dan bahasa". ${ }^{5}$ Adapun jenis penelitian kualitatif yang digunakan oleh peneliti adalah menggunakan jenis penelitian

\footnotetext{
${ }^{4}$ Siti Mutawaqilah, Wawancara, Banjarwati Paciran Lamongan, 8 April 2019. Pada 09.40-10.00 WIB.

${ }^{5}$ Lexy J.Moleong, Metodologi Penelitian Kualitatif (Bandung: PT Remaja Rosdakarya, 2014), 6.
} 
deskriptif. Menurut Whitney yang dikutip oleh Moh Nazir bahwa metode deskriptif adalah pencarian fakta dengan interpretasi yang tepat, yang mana dalam penelitian deskriptif ini mempelajari masalah-masalah dalam masyarakat, serta tata cara yang berlaku dalam masyarakatmasyarakat serta situs-situs tertentu, termasuk tentang hubungan- hubungan, kegiatan-kegiatan, sikap-sikap, pandangan-pandangan, serta proses-proses yang sedang berlangsung dan pengaruhpengaruh dari suatu fenomena. ${ }^{6}$

\section{Deskripsi Latar Penelitian}

Dalam penelitian ini, peneliti mengambil fokus terhadap manajemen kepala sekolah dalam menumbuhkan budaya religius peserta didik. Manajemen kepala sekolah merupakan proses yang dilakukan oleh kepala sekolah dalam mengatur dan mengelola sekolahannya dengan sedemikian rupa agar dapat berkembang dengan baik dan menjadi sekolah yang berkualitas. Proses manajerial yang dilakukan oleh kepala sekolah ini meliputi perencanaan, pengorganisasian, pelaksanaan sampai dengan tahap pengawasan, proses-proses ini dilakukan untuk mencapai tujuan yang telah ditetapkan bersama. Salah satu fungsi kepala sekolah yaitu perencana sekolah yang mana seorang kepala sekolah harus mampu menetapkan arah sekolah sebagai lembaga pendidikan dengan cara merumuskan visi, misi, tujuan dan strategi pencapaian. SDN Banjarwati memiliki visi "UNGGUL DALAM PRESTASI DAN BERAKHLAK MULIA” untuk mewujudkan visi tersebut kepala sekolah SDN Banjarwati merumuskan kegiatan-kegiatan religius disamping adanya mata pelajaran PAI (Pendidikan Agama Islam) guna terciptanya peserta didik yang berakhlak mulia. Dengan diadakannya kegitan-kegiatan religius tersebut diharapkan peserta didik dapat mengimplementasikannya dikehidupan sehari-hari dan dimanapun mereka berada.

\section{Instrumen Penelitian}

Dalam penelitian ini, yang menjadi instrumen utama adalah peneliti sendiri atau anggota tim peneliti atau sering disebut human instrument yang berfungsi menetapkan fokus penelitian, memilih informan sebagai sumber data, melakukan pengumpulan data, menilai kualitas data, analisis data,menafsirkan data dan membuat kesimpulan atas temuannya. Instrumen penelitian dijadikan sebagai alat bantu yang digunakan untuk dapat memperoleh data yang dibutuhkan dan juga dibantu dengan alat-alat yang digunakan untuk mengumpulkan data-data, seperti buku catatan, tipe recorder dan kamera. Dalam penelitian ini, penulis menggunakan data penelitian bersifat kualitatif, data yang ditampilkan dalam bentuk observasi, wawancara, dan dokumentasi. Dalam proses observasi, wawancara, dan dokumentasi yang dilakukan oleh peneliti. Pada proses wawancara tersebut diajukan pada narasumber atau informansebagai berikut: kepala sekolah, guru

\footnotetext{
${ }^{6}$ Moh Nazir, Metode Penelitin (Jakarta: PT Ghalia Indonesia, 2003), 16.
} 
mata pelajaran Pendidikan Agama Islam, guru pembimbing dan peserta didik.

\section{Data dan Sumber Data}

Sumber data adalah subjek dari mana data diperoleh. ${ }^{7}$ Yang juga dapat diartikan sember dari mana data tersebut diperoleh baik itu berbentuk kata- kata, tindakan maupun dokumentasi dan lain-lain. Dan untuk menyelesaikan masalah dalam penelitian ini, maka peneliti mencari data-data dari beberapa sumber yang berkaitan dengan manajemen kepala sekolah dalam menumbuhkankan budaya religius peserta didik di SDN Banjarwati di antaranya mempersiapkan data primer sebagai data utama dan data sekunder sebagai data pendukung dalam penelitian ini.

\section{Data Primer}

Data primer pada penelitian ini diperoleh dari sumber pertama melalui prosedur dan teknik pengambilan data yang dapat berupa interview, observasi, maupun penggunaan instrument yang khusus dirancang sesuai dengan tujuan. ${ }^{8}$ Dapat diartikan juga data yang diperoleh secara langsung dari lapangan.

\section{Data Sekunder}

Data sekunder pada penelitian ini merupakan data yang diperoleh dari sumber sampingan dan biasanya berupa data dokumentasi dan arsip-arsip resmi.

\section{Prosedur Pengumpulan Data}

Observasi

Penelitian kualitatif menggunakan metode pengumpulan data dengan observasi. Metode ini digunakan untuk mendapatkan data yang lebih lengkap dan mengetahui tingkat kemampuan yang tampak. Observasi atau pengamatan merupakan suatu teknik atau cara pengumpulan data dengan jalan mengadakan pengamatan terhadap kegiatan yang sedang berlangsung. ${ }^{9}$

Intervew (wawancara)

Penelitian kualitatif menggunakan metode pengumpulan data dengan interview atau wawancara. Interview atau wawancara merupakan pertemuan dua orang untuk bertukar informasi dan ide melalui tanya jawab, sehingga dapat dikonstruksikan makna dalam topik tertentu. ${ }^{10}$

\section{Dokumentasi}

Penelitian kulitatif juga menggunakan metode pengumpulan data dengan metode dokumentasi. Dokumentasi ini berasal dari kata dokumen, yang berarti bahan-bahan tertulis. Dokumen merupakan catatan peristiwa yang sudah berlalu, bisa berbentuk tulisan, gambar, atau

\footnotetext{
${ }^{7}$ Suharsimi Arikunto, Prosedur Penelitian: Suatu Pendekatan Praktek (Jakarta: PT Rineka Cipta, 2002), 107.

8 Saifuddin Azwar, Metode Penelitian (Yogyakarta: PT Pustaka Pelajar, 2005), 36.

${ }^{9}$ Nana Syaodah Sukamdinata, Metode Penelitian Pendidikan (Bandung: PT Remaja Rosdakarya, 2008), 220.

10 Sugiyono, Metode Penelitian (Bandung: Penerbit Alfa Beta, 2015), 317
} 
karya-karya monumental dari seseorang. ${ }^{11}$ Telaah dokumentasi merupakan salah satu teknik penting dalam suatu penelitian dengan mengumpulkan informasi yang telah ada pada lembaga terkait.

\section{Teknik Analisis Data}

Menurut Miles and Huberman, "Aktivitas dalam analisis data kualitatif dilakukan secara interaktif dan berlangsung secara terus menerus sampai tuntas, sehingga datanya sudah jenuh. Aktivitas dalam analisis data, yaitu, data reduction, data display, dan conclusion drowing/verification"12

\section{Keabsahan Data}

Selain menganalisis data, peneliti juga harus menguji keabsahan data agar memperoleh data yang valid. Untuk menetapkan keabsahan data tersebut diperlukan teknik pemeriksaan. Uji keabsahan data dalam penelitian ini menggunakan uji kreadibilitas, uji kreadibilitas data atau kepercayaan terhadap data hasil penelitian dalam penelitian ini menggunakan teknik triangulasi. ${ }^{13}$

\section{Temuan Penelitian dan Pembahasan}

Upaya-upaya yang dilakukan kepala sekolah SDN Banjarwati untuk menumbuhkan budaya religius peserta didik yakni dengan cara mengadakan dan menerapkan kegiatankegiatan yang bersifat islami, yang mana kegiatan-kegiatan tersebut masih ada sangkut pautnya dengan pembelajaran dikelas, sehingga diharapkan materi yang disampikan dikelas juga dapat dipraktekkan melalui kegiatan-kegiatan tersebut.

Adapun program-program religius yang diadakan SDN Banjarwati beserta manajerialnya yakni sebagai berikut :

1. Apel Pagi atau Do’a Bersama Sebelum Memasuki Ruang Kelas

\begin{tabular}{|l|l|l|l|}
\hline No & \multicolumn{1}{|c|}{ Manajemen } & \multicolumn{2}{|c|}{ Langkah-langkah manajemen } \\
\hline 1. & Perencanaan & a. Latar & -Untuk mendisiplinkan peserta didik \\
& & belakang dan & agar tidak terlambat ke sekolah \\
& tujuan & -Untuk membiasakan peserta didik \\
& & selalu berdo'a terlebih dahulu sebelum \\
& & melakukan aktifitas apapun, minimal \\
& & dengan membaca Bismillab. \\
\hline
\end{tabular}

\footnotetext{
${ }^{11}$ Suharsimi Arikunto, Prosedur Penelitian : Suatu Pendekatan Praktek (Jakarta: PT Rineka Cipta, 2002), 132.

12 Sugiyono, Metode Penelitian Pendidikan,: Pendekatan Kuantitatif, Kualitatif, dan R\&D (Bandung: Alfabeta, 2016$), 246$.

${ }^{13}$ Lexy J.Moeleng, Metodologi Penelitian Kualitatif (Bandung: PT Remaja Rosdakarya, 2014), 178.
} 


\begin{tabular}{|l|l|l|l|}
\hline No & \multicolumn{1}{|c|}{ Manajemen } & \multicolumn{2}{|c|}{ Langkah-langkah manajemen } \\
\hline & \multirow{2}{*}{$\begin{array}{l}\text { b. Waktu } \\
\text { 2. }\end{array}$} & $\begin{array}{l}\text { Dilakukan setiap pagi hari, } \\
\text { tepatnya pukul 06:45 WIB di } \\
\text { halaman depan sekolah. }\end{array}$ \\
\cline { 3 - 4 } & Pengorganisasian & $\begin{array}{l}\text { Kepala sekolah, dewan guru dan } \\
\text { seluruh pesera didik SDN } \\
\text { Bepanjarwati. }\end{array}$ \\
\hline 3. & Pelaksanaan & $\begin{array}{l}\text { Bepada guru pembimbing siswa yakni Bapak Drs. Harsilo. } \\
\text { berdo'a dengan dipimpin oleh salah satu peserta didik. }\end{array}$ \\
\hline 4. & $\begin{array}{l}\text { Pengawasan atau } \\
\text { evaluasi }\end{array}$ & $\begin{array}{l}\text { Evaluasi berjalan menyesuaikan permasalahan yang } \\
\text { ditemukan, kemudian didiskusikan bersama dan mencari } \\
\text { jalan keluar atau solusi terbaik untuk permasalahan } \\
\text { tersebut. Contoh permasalahan; 1) terlambat mengikuti apel } \\
\text { pagi atau do'a bersama, solusinya diberdirikan setelah } \\
\text { kegiatan selesai. 2) ramai saat berlangsungnya kegiatan, } \\
\text { solusinya ditegur. }\end{array}$ \\
\hline
\end{tabular}

2. Sholat Dhuha

\begin{tabular}{|c|c|c|c|}
\hline No & Manajemen & \multicolumn{2}{|c|}{ Langkah-langkah manajemen } \\
\hline \multirow[t]{3}{*}{1.} & Perencanaan & $\begin{array}{l}\text { a. Latar } \\
\text { belakang dan } \\
\text { t ujuan }\end{array}$ & $\begin{array}{l}\text { - Agar peserta didik menjadi disiplin, } \\
\text { rajin, terbiasa. } \\
\text { - Agar peserta didik tidak lalai dalam } \\
\text { mengerjakan ibadahnya. }\end{array}$ \\
\hline & & b. Waktu & $\begin{array}{l}\text { Pada jam istirahat pertama } \\
\text { pukul 09:30 WIB. }\end{array}$ \\
\hline & & c. Sasaran & $\begin{array}{l}\text { Seluruh peserta didik SDN } \\
\text { Banjarwati kecuali kelas } 1 \text { dan } 2 .\end{array}$ \\
\hline 2. & Pengorganisasian & \multicolumn{2}{|c|}{$\begin{array}{l}\text { Yang bertanggug ialah Bapak Harsilo selaku guru bidang } \\
\text { kerohanian. }\end{array}$} \\
\hline 3. & Pelaksanaan & $\begin{array}{l}\text { Dilaksanakan } \\
\text { dikerjakan hany }\end{array}$ & $\begin{array}{l}\text { seperti sholat shubuh yang } \\
2 \text { raka'at. Yang membedakan niatnya dan }\end{array}$ \\
\hline
\end{tabular}




\begin{tabular}{|l|l|l|}
\hline & & $\begin{array}{l}\text { tidak ada qunut dalam sholat dhuha dan memiliki } \\
\text { wudhu. }\end{array}$ \\
\hline 4. & $\begin{array}{l}\text { Pengawasan atau } \\
\text { evaluasi }\end{array}$ & $\begin{array}{l}\text { Evaluasi yang dilakukan berjalan sesuai permasalahan yang } \\
\text { ditemukan, kemudian didiskusikan bersama dan dicarikan } \\
\text { solusi untuk masalah tersebut. Contoh permasalahan: 1) } \\
\text { peserta didik yang tidak mengerjakan sholat dhuha. 2) } \\
\text { peserta didik yang ramai ketika mengerjakan sholat. Untuk } \\
\text { solusinya yaitu dihukum membersihkan kamar mandi, } \\
\text { tempat wudhu, musholah dan mereka juga akan dihukum } \\
\text { membaca sholawat nariyah 100x, dan menghafal surat-surat } \\
\text { pendek beserta artinya. }\end{array}$ \\
\hline
\end{tabular}

3. Sholat Dhuur Berjama’ah

\begin{tabular}{|c|c|c|c|}
\hline No & Manajemen & \multicolumn{2}{|c|}{ Langkah-langkah manajemen } \\
\hline \multirow[t]{3}{*}{1.} & Perencanaan & $\begin{array}{l}\text { a. Latar } \\
\text { belakang } \\
\text { dan tujuan }\end{array}$ & $\begin{array}{l}\text { - Untuk membiasakan peserta didik } \\
\text { mengerjakan sholat tepat waktu dan } \\
\text { dilakukan secara berjama'ah. } \\
\text { - Untuk memotivasi peserta didik agar } \\
\text { tidak sekali-kali } \\
\text { meninggalkan } \\
\text { sholatnya. }\end{array}$ \\
\hline & & b. Waktu & $\begin{array}{l}\text { Setelah terdengar adzan dhuhur, tepatnya } \\
\text { pada saat istirahat kedua } \\
\text { pukul 11:00 WIB. }\end{array}$ \\
\hline & & c. Sasaran & $\begin{array}{l}\text { Seluruh peserta didik mulai dari } \\
\text { kelas } 3 \text { sampai kelas } 6 \text {. }\end{array}$ \\
\hline 2. & Pengorganisasian & \multicolumn{2}{|c|}{$\begin{array}{l}\text { Yang bertanggung jawab ialah Bapak Harsilo selaku guru } \\
\text { bidang kerohanian. }\end{array}$} \\
\hline 3. & Pelaksanaan & \multicolumn{2}{|c|}{$\begin{array}{l}\text { Dilakukan di mushollah sekolah. Untuk tata cara gerakan } \\
\text { sholat seperti pada umumnya. Yang membedakan sholat ini } \\
\text { dikerjakan secara berjama'ah. Dan sholat dhuhur ini } \\
\text { diimami oleh pak Harsilo. }\end{array}$} \\
\hline
\end{tabular}




\begin{tabular}{|c|c|c|}
\hline 4. & $\begin{array}{l}\text { Pengawasan atau } \\
\text { evaluasi }\end{array}$ & $\begin{array}{l}\text { Evaluasi yang dilakukan berjalan sesuai permasalahan yang } \\
\text { ditemukan, kemudian didiskusikan bersama dan dicarikan } \\
\text { solusi untuk masalah tersebut. Contoh permasalahan: 1) } \\
\text { peserta didik yang tidak mengikuti sholat dhuhur } \\
\text { berjama'ah. 2) peserta didik yang ramai ketika mengerjakan } \\
\text { sholat. Untuk solusinya yaitu dihukum membersihkan } \\
\text { kamar mandi, tempat wudhu, musholah dan mereka juga } \\
\text { akan dihukum membaca sholawat nariyah 100x, dan } \\
\text { menghafal surat-surat pendek beserta artinya }\end{array}$ \\
\hline
\end{tabular}

4. Membaca Al-Qur'an, Juz Amma dan Asma'ul Husnah

\begin{tabular}{|c|c|c|c|}
\hline No & Manajemen & \multicolumn{2}{|c|}{ Langkah-langkah manajemen } \\
\hline \multirow[t]{3}{*}{1.} & Perencanaan & $\begin{array}{l}\text { a. Latar } \\
\text { belakang dan } \\
\text { tujuan }\end{array}$ & $\begin{array}{l}\text { - Untuk membiasakan peserta didik } \\
\text { membaca Al-Qur'an, surat-surat } \\
\text { pendek (Juz 'amma) dan asma'ul } \\
\text { khusna di setiap harinya agar peserta } \\
\text { didik menjadi lebih lancar dalam } \\
\text { membacanya. } \\
\text { - Peserta didik ditekankan untuk } \\
\text { menghafal lafal-lafalnya } \\
\text { sekaligus artinya, dan mengerti } \\
\text { maksud tujuannya. }\end{array}$ \\
\hline & & b. Waktu & $\begin{array}{l}\text { - Pada jam istirahat untuk mengisi } \\
\text { waktu luang sebelum maupun } \\
\text { setelah sholat. }\end{array}$ \\
\hline & & c. Sasaran & $\begin{array}{l}\text { - Seluruh peserta didik mulai dari kelas } \\
3 \text { sampai kelas } 6 .\end{array}$ \\
\hline 2. & Pengorganisasian & \multicolumn{2}{|c|}{$\begin{array}{l}\text { Yang bertanggung jawab ialah Bapak Harsilo selaku guru } \\
\text { bidang kerohanian. }\end{array}$} \\
\hline 3. & Pelaksanaan & \multicolumn{2}{|c|}{$\begin{array}{l}\text { Dengan cara membentuk kelompok kecil secara melingkar, } \\
\text { untuk memudahkan dalam mengotrol dan mengawasi } \\
\text { peserta didik. Dan saat penyetoran hafalan-hafalan peserta } \\
\text { didik secara langsung berhadapan dengan Bapak Harsilo. }\end{array}$} \\
\hline
\end{tabular}




\begin{tabular}{|l|l|l|}
\hline 4. & Pengawasan atau \\
evaluasi & $\begin{array}{l}\text { Evaluasi yang dilakukan berjalan sesuai permasalahan yang } \\
\text { ditemukan, kemudian didiskusikan bersama dan dicarikan } \\
\text { solusi untuk masalah tersebut. Contoh permasalahan: 1) } \\
\text { peserta didik yang belum lancar dalam membaca Al- } \\
\text { Qur'an, juz 'ammah dan asma'ul khusna, solusinya yaitu } \\
\text { akan dibimbing langsung oleh guru pembimbing. 2) peserta } \\
\text { didik yang ramai dan mengganggu temannya yang sedang } \\
\text { membaca Al- Qur'an, juz 'ammah dan asma'ul khusna, } \\
\text { solusinya yaitu akan dihukum membaca sholawat nariyah } \\
\text { sebanyak 100 kali. 3) peserta didik yang sengaja tidak } \\
\text { mengikuti kegiatan membaca Al-Qur'an, juz 'ammah dan } \\
\text { asma'ul khusna, solusinya yaitu dihukum membersihkan } \\
\text { kamar mandi, tempat wudhu, atau mushollah. }\end{array}$ \\
\hline
\end{tabular}

Seperti yang telah diuraikan pada, bahwa fungsi-fungsi manajemen yang paling umum digunakan ialah fungfi-fungsi msnajemen menurut G. R. Terry, yang mana fungsi-fungsi manajemen dibagi menjadi empat bagian, yakni planning (perencanaan), organizing (pengorganisasian), actuating (pengarahan) dan controlling (pengawasan). ${ }^{14}$

a. Perencanaan (Planning)

Adapun kegiatan-kegiatan dalam perencanaan, diantaranya :

1) Menyusun seluruh rancangan kerja

2) Menentukan tentang persoalan yang dihadapi, kapan, dan bagaimana mengatasinya

3) Menetapkan dan merumuskan tujuan yang hendak dicapai

4) Merumuskan strategi untuk mencapai tujuan tersebut

5) Menentukan sumber-sumber daya yang diperlukan, dan menjabarkan kelebihan dan kekurangannya

6) Menetapkan standar/indikator keberhasilan dalam pencapaian tujuan tersebut

b. Pengorganisasian (organizing)

1) Adapun kegiatan-kegiatan dalam pengorganisasian, diantaranya;

2) Mengalokasikan sumber daya, merumuskan dan menetapkan tugas, dan menetapkan prosedur yang diperlukan.

14 Saefullah, Manajemen Pendidikan Islam (Bandung: CV Pustaka Setia, 2012), 9. 
3) Menetapkan struktur organisasi yang menunjukkan adanya garis kewenangan dan tanggungjawab

4) Kegiatan penempatan sumber daya manusia pada posisi yang paling tepat

c. Pengarahan (actuating/directing)

1) Adapun kegiatan-kegiatan dalam pengarahan, diantaranya:

2) Mengimplementasikan proses kepemimpinan, pembimbingan, dan pemberian motivasi kepada anggotanya agar dapat bekerja secara efektif dan efisien untuk mencapai tujuan yang ditetapkan

3) Memberikan tugas dan penjelasan mengenai pekerjaan kepada anggotanya

4) Menjelaskan kebijakan yang telah ditetapkan

d. Pengawasan (controlling)

1) Adapun kegiatan-kegiatan dalam pengawasan, diantaranya;

2) Mengevaluasi keberhasilan dalam pencapaian tujuan sesuai indikator yang telah ditetapkan

3) Mengambil langkah klarifikasi dan koreksi atas penyimpangan yang mungkin ditemukan

4) Melakukan berbagai alternatif solisi atas berbagai masalah yang berkaitan dengan pencapaian tujuan

Jadi secara umum, berdasarkan kesimpulan hasil wawancara diatas, dapat diartikan bahwa secara tidak langsung kepala sekolah SDN Banjarwati tidak melakukan semua langkah-langkah manajemen dengan baik, melainkan hanya beberapa poin-poin pentingnya saja. Dan juga berdasarkan hasil observasi yang peneliti lakukan di SDN Banjarwati bahwa program-program religius yang diadakan di SDN Banjarwati tidak ada dokumentasi dan struktur manajerial khusus, sehingga saat dibutuhkan untuk dijadikan sebagai barang bukti bahwa programprogram tersebut benar-benar diadakan di SDN Banjarwati tidak ada buktinya.Ini berbanding terbalik yang mana seharusnya disetiap program- program yang diadakan oleh lembaga diharuskan untuk memiliki manajerial khusus dan disertai dokumen-dokumen lainnya untuk dijadikan arsip lembaga yang mana nantinya akan dilaporkan kepada pihak UPT Dinas Pendidikan.

\section{Kesimpulan}

Berdasarkan hasil penelitian, Manajemen kepala sekolah dalam menumbuhkan budaya religius peserta didik di SDN Banjarwati adalah suatu bentuk usaha yang dilakukan oleh kepala sekolah SDN Banjarwati dengan cara mengadakan berbagai program-program yang dapat 
membentuk karakter religius peserta didik yang taat menjalankan segala perintah-Nya dan menjauhi segala larangan- Nya, dan dengan adanya program-program religius tersebut dapat menjadi suatu kebiasaan berperilaku dan bertindak yang baik bagi peserta didik serta dapat menjadikan peserta didik yang berakhlakul karimah. Upaya-upaya yang dilakukan kepala sekolah SDN Banjarwati untuk menumbuhkan budaya religius peserta didik yakni dengan cara mengadakan dan menerapkan kegiatan-kegiatan yang bersifat islami, yang mana kegiatankegiatan tersebut masih ada sangkut pautnya dengan pembelajaran dikelas, sehingga diharapkan materi yang disampikan dikelas juga dapat dipraktekkan melalui kegiatan-kegiatan tersebut. Adapun kegiatan-kegiatan religius yang diadakan SDN Banjarwati yakni sebagai berikut: (a) Apel Pagi atau Do’a Bersama Sebelum Memasuki Ruang Kelas, (b) Sholat Dhuha, (c) Sholat Dhuhur Berjama'ah, (d) Membaca Al-Qur'an, Juz Amma dan Asma'ul Khusnah. Dan Secara tidak langsung kepala sekolah SDN Banjarwati tidak melakukan semua langkahlangkah manajemen dengan baik, melainkan hanya beberapa poin-poin pentingnya saja. Dan juga program-program religius yang diadakan di SDN Banjarwati tidak ada dokumentasi dan struktur manajerial khusus, sehingga saat dibutuhkan untuk dijadikan sebagai barang bukti bahwa program-program tersebut benar-benar diadakan di SDN Banjarwati.

\section{Daftar Kepustakaan}

Arikunto, Suharsimi. Prosedur Penelitian: Suatu Pendekatan Praktek. Jakarta: PT Rineka Cipta, 2002. Azwar, Saifuddin. Metode Penelitian, Yogyakarta: PT Pustaka Pelajar, 2005

Moleong, Lexy J. Metodologi Penelitian Kualitatif. Bandung: PT Remaja Rosdakarya, 2014.

Nazir, Moh. Metode Penelitin. Jakarta: PT Ghalia Indonesia, 2003

Sukamdinata, Nana Syaodah. Metode Penelitian Pendidikan. Bandung: PT Remaja Rosdakarya, 2008.

Saefullah, Manajemen Pendidikan Islam. Bandung: CV Pustaka Setia, 2012

Sugiyono, Metode Penelitian. Bandung: Penerbit Alfa Beta, 2015.

Metode Penelitian Pendidikan: Pendekatan Kuantitatif, Kualitatif, dan R\&D. Bandung: Alfabeta, 2016.

Undang-undang Republik Indonesia Nomor 20 Tahun 2003 tentang Sistem Pendidikan Nasional, Bab 1 Ketentuan Umum pasal 1 ayat 1

Wahjosumidjo. Kepemimpinan Kepala Sekolah. Jakarta: Rajawali Pers, 2008 